\title{
Impaired 24,25-Dihydroxyvitamin D \\ Production in Anephric Human and Pig
}

\author{
Ronald L. Horst, E. Travis Littledike, Richard W. Gray, and Joseph L. NaPoli, \\ National Animal Disease Center, Agricultural Research, Science and Education \\ Administration, U. S. Department of Agriculture, Ames, Iowa 50010; Medical \\ College of Wisconsin, Clinical Research Center, Milwaukee, Wisconsin 53226; \\ Southwest Medical School, Dallas, Texas 7523.5
}

A в S T R A C T Plasma 25-hydroxyvitamin D and 24, 25-dihydroxy-vitamin $\mathrm{D}\left[24,25-(\mathrm{OH})_{2} \mathrm{D}\right]$ concentrations were measured in normal and chronically dialyzed anephric humans and pigs. Measurement of the 24, $25-(\mathrm{OH})_{2} \mathrm{D}$ was preceded by three purification steps involving one Sephadex LH-20 column and two high-pressure liquid chromatographic columns. The final high-pressure liquid chromatography step involved resolution of 25-hydroxy-vitamin $D_{3}-26,23$ lactone and 25,26-dihydroxy-vitamin $\mathrm{D}_{2}$ from 24,25dihydroxyvitamin $\mathrm{D}_{2}$ and 24,25-dihydroxyvitamin $\mathrm{D}_{3}$ $\left[24,25-(\mathrm{OH})_{2} \mathrm{D}_{3}\right]$. The total 25-hydroxyvitamin D [25hydroxyvitamin $\mathrm{D}_{2}$ plus 25-hydroxyvitamin $\mathrm{D}_{3}$ (25$\left.\mathrm{OHD}_{3}\right)$ ] was $31.7 \pm 3.6 \mathrm{ng} / \mathrm{ml}$ in the plasma of eight anephric human subjects and $40.1 \pm 3.7 \mathrm{ng} / \mathrm{ml}$ in five normal human subjects. Six of the eight anephric patients had undetectable $(<0.2 \mathrm{ng} / \mathrm{ml}) 24,25-(\mathrm{OH})_{2} \mathrm{D}$ concentrations. Two of the eight patients had very low $(0.51$ and $0.41 \mathrm{ng} / \mathrm{ml})$, but detectable, 24,25dihydroxyvitamin $D_{2}$. The normal human volunteers had plasma $24,25-(\mathrm{OH})_{2} \mathrm{D}$ concentrations of $2.8 \pm 0.7$ $\mathrm{ng} / \mathrm{ml}$. Chronically dialyzed anephric and normal pigs were given intramuscular injections of massive amounts $\left(5 \times 10^{6} \mathrm{IU}\right)$ of vitamin $\mathrm{D}_{3}$ immediately after surgery (day 0 ) and again on day 7 . In anephric pigs, plasma $25-\mathrm{OHD}_{3}$ progressively rose from $12 \pm 4 \mathrm{ng} / \mathrm{ml}$ on day 0 to $705 \pm 62 \mathrm{ng} / \mathrm{ml}$ on day 10 . The $25-\mathrm{OHD}_{3}$ concentrations in normal pigs rose from $8 \pm 2 \mathrm{ng} / \mathrm{ml}$ on day 0 to $439 \pm 64 \mathrm{ng} / \mathrm{ml}$ on day 10 . Plasma $25-\mathrm{OHD}_{3}$ was higher in anephrics throughout the experiment, and concentrations were significantly higher $(P<0.05)$ on days 9 and 10. Plasma $24,25-(\mathrm{OH})_{2} \mathrm{D}_{3}$ concentrations declined progressively in anephric pigs from $3.6 \pm 0.6 \mathrm{ng} / \mathrm{ml}$ on day 0 to $3.2 \pm 0.7 \mathrm{ng} / \mathrm{ml}$ on day 2 .

Address reprint requests to Dr. Ronald L. Horst, National Animal Disease Center, Ames, Iowa.

Received for publication 19 May 1980 and in revised form 4 August 1980.
During days $4-10$, plasma $24,25-(\mathrm{OH})_{2} \mathrm{D}_{3}$ was not apparent until plasma $25-\mathrm{OHD}_{3}$ was $>400 \mathrm{ng} / \mathrm{ml}$. In control pigs, plasma $24,25-(\mathrm{OH})_{2} \mathrm{D}_{3}$ was elevated from $4.3 \pm 0.6 \mathrm{ng} / \mathrm{ml}$ on day 0 to $178 \pm 2.7 \mathrm{ng} / \mathrm{ml}$ on day 3 . Plasma $24,25-(\mathrm{OH})_{2} \mathrm{D}_{3}$ was significantly higher $(P$ $<0.05)$ in controls on days $1-8$. At the end of the experiment (day 10), 24,25- $(\mathrm{OH})_{2} \mathrm{D}_{3}$ concentrations were similar and not significantly different in both groups $(87.0 \pm 18.4 \mathrm{ng} / \mathrm{ml}$ in anephric and $110.3 \pm 32.1 \mathrm{ng} / \mathrm{ml}$ in normal pigs). The identity of the $24,25-(\mathrm{OH})_{2} \mathrm{D}_{3}$ isolated from anephric pig plasma was confirmed by mass spectroscopy. Our data suggest that anephric humans receiving normal dietary levels of vitamin $D_{3}$ have little or no ability to produce $24,25-(\mathrm{OH})_{2} \mathrm{D}$. However, we have shown that pigs produce 24,25$(\mathrm{OH})_{2} \mathrm{D}_{3}$ when plasma $25-\mathrm{OHD}_{3}$ is extremely high $(>400 \mathrm{ng} / \mathrm{ml}$ ).

\section{INTRODUCTION}

The role of the kidney in the formation of active vitamin $D_{3}$ metabolites has been shown in many laboratories (1-3). Nephrectomy stops bioproduction of 1,25-dihydroxyvitamin $\mathrm{D}_{3}\left[1,25-(\mathrm{OH})_{2} \mathrm{D}_{3}\right]^{1}(4)$ or the newly discovered vitamin $\mathrm{D}_{3}$ metabolite, 25-hydroxyvitamin $\mathrm{D}_{3}-26,23$ lactone (25-OHD $-26,23$ lactone) (5). However, there is still some question whether 24, 25-dihydroxyvitamin $\mathrm{D}\left[24,25-(\mathrm{OH})_{2} \mathrm{D}\right]$ is exclusively a product of the kidney. Garabedian et al. (6) showed the production of a polar peak in anephric rats given large doses of $\left[{ }^{3} \mathrm{H}\right] 25$-hydroxyvitamin $D_{3}\left(\left[{ }^{3} \mathrm{H}\right]\right.$ $25-\mathrm{OHD}_{3}$ ). By means of the polar peak's periodate sensitivity and comigration with authentic 24,25dihydroxyvitamin $\mathrm{D}_{3}\left[24,25-(\mathrm{OH})_{2} \mathrm{D}_{3}\right]$ on Sephadex

\footnotetext{
' Abbreviations used in this paper: HPLC, high-pressure liquid chromatography; OHD, hydroxyvitamin $\mathrm{D} ;(\mathrm{OH})_{2} \mathrm{D}$, dihydroxyvitamin $\mathrm{D} ; 25-\mathrm{OHD}_{3}$-26,23 lactone, 25-hydroxyvitamin $\mathrm{D}_{3}-26,23$ lactone.
} 
$\mathrm{LH}-20$, it was identified as $24,25-(\mathrm{OH})_{2} \mathrm{D}_{3}$. However, no mass spectra data were published to confirm their beliefs. Haddad et al. (7) recently reported concentrations of $3.0 \mathrm{ng} / \mathrm{ml}$ of $24,25-(\mathrm{OH})_{2} \mathrm{D}$ in both anephric and normal humans. Horst et al. (8) and Shepard et al. (9) reported $24,25-(\mathrm{OH})_{2} \mathrm{D}$ at concentrations of 0.8 and $1.9 \mathrm{ng} / \mathrm{ml}$, respectively, in anephric human plasma. In all three studies normal 25-hydroxyvitamin D (25-OHD) concentrations $(15-40 \mathrm{ng} / \mathrm{ml})$ were observed in normal subjects and anephric patients. In contrast to the measurable $24,25-(\mathrm{OH})_{2} \mathrm{D}$ found by some workers (7-9), Taylor (10) failed to detect $24,25-(\mathrm{OH})_{2} \mathrm{D}$ in plasma of anephric man with normal or above normal 25-OHD concentrations. These conflicting reports are undoubtedly due to the different ways of measuring $24,25-(\mathrm{OH})_{2} \mathrm{D}_{3}$ in plasma-lipid extracts. Information concerning $24,25-(\mathrm{OH})_{2} \mathrm{D}$ concentrations (or production) in anephric patients is important because its presence may be required for the function of $1,25-(\mathrm{OH})_{2} \mathrm{D}_{3}$ in the normal healing of osteomalacia in humans (11).

The results of this report show that the amount of $24,25-(\mathrm{OH})_{2} \mathrm{D}$ is very low to nondetectable in anephric human plasma. However, we will show that anephric pigs produce $24,25-(\mathrm{OH})_{2} \mathrm{D}_{3}$ when plasma $25-\mathrm{OHD}_{3}$ concentrations are elevated to $>400 \mathrm{ng} / \mathrm{ml}$ by massive intramuscular injections of vitamin $\mathrm{D}_{3}$.

\section{METHODS}

Sterols and assays. 25- $\mathrm{OHD}_{3}$ was a gift from the Upjohn Company, Kalamazoo, Mich. Vitamin $\mathrm{D}_{3}$ was purchased from Sigma Chemical Co., St. Louis, Mo. $24,25-(\mathrm{OH})_{2} \mathrm{D}_{3}$ was a gift from Hoffman-La Roche, Nutley, N. J. 24,25-Dihydroxyvitamin $\mathrm{D}_{2}\left[24,25-(\mathrm{OH})_{2} \mathrm{D}_{2}\right]$ on 25,26-dihydroxyvitamin $\mathrm{D}_{2}\left[25,26-(\mathrm{OH})_{2} \mathrm{D}_{2}\right]$ were isolated and identified from vitamin $\mathrm{D}_{2}$-toxic plasma. ${ }^{2}$ Concentrations of all metabolites used as standards (originating from vitamin $\mathrm{D}_{2}$ or $\mathrm{D}_{3}$ ) were measured in $100 \% \mathrm{ETOH}\left(\mathrm{E}_{\max }=18,200 \sim 264 \mathrm{~nm}\right)$ with a Beckman DB scanning spectrophotometer (Beckmann Instruments, Fullerton, Calif.).

The procedure for the purification of the $24,25-(\mathrm{OH})_{2} \mathrm{D}$ and 25-OHD for assay is shown in Fig. 1. Briefly, plasma lipids were removed by extracting plasma twice with 3 vol peroxide-free diethyl ether and once with 4 vol $1: 3$ $\mathrm{MeOH}: \mathrm{MeCl}_{2}$. The lipid extracts were purified for measurement of $25-\mathrm{OHD}$ and $24,25-(\mathrm{OH})_{2} \mathrm{D}$ by a modification of the procedure of Horst et al. (8). They proposed a method of quantify: $24,25-(\mathrm{OH})_{2} \mathrm{D}$ and $25,26-(\mathrm{OH})_{2} \mathrm{D}$ by radioligand binding assay after purification by high-pressure liquid chromatography (HPLC) on a Zorbax Sil column (Dupont Instruments, Wilmington, Del.) developed in 11:89 isopropanol:hexane. We have found that the $24,25-(\mathrm{OH})_{2} \mathrm{D}$ region of this column contains not only $24,25-(\mathrm{OH})_{2} \mathrm{D}_{2}$ and $24,25-(\mathrm{OH})_{2} \mathrm{D}_{3}$, but also $25,26-(\mathrm{OH})_{2} \mathrm{D}_{2}$ and $25-\mathrm{OHD}_{3}-26,23$ lactone (Fig. 2). In addition, Horst et al. (8) found material that competed in the binding assay that migrated very near the $24,25-(\mathrm{OH})_{2} \mathrm{D}$ region of this column. This material, designated as peak I, was five- to sixfold

${ }^{2}$ Horst, R. L., E. T. Littledike, J. L. Riley, and J. L. Napoli. Manuscript submitted for publication.

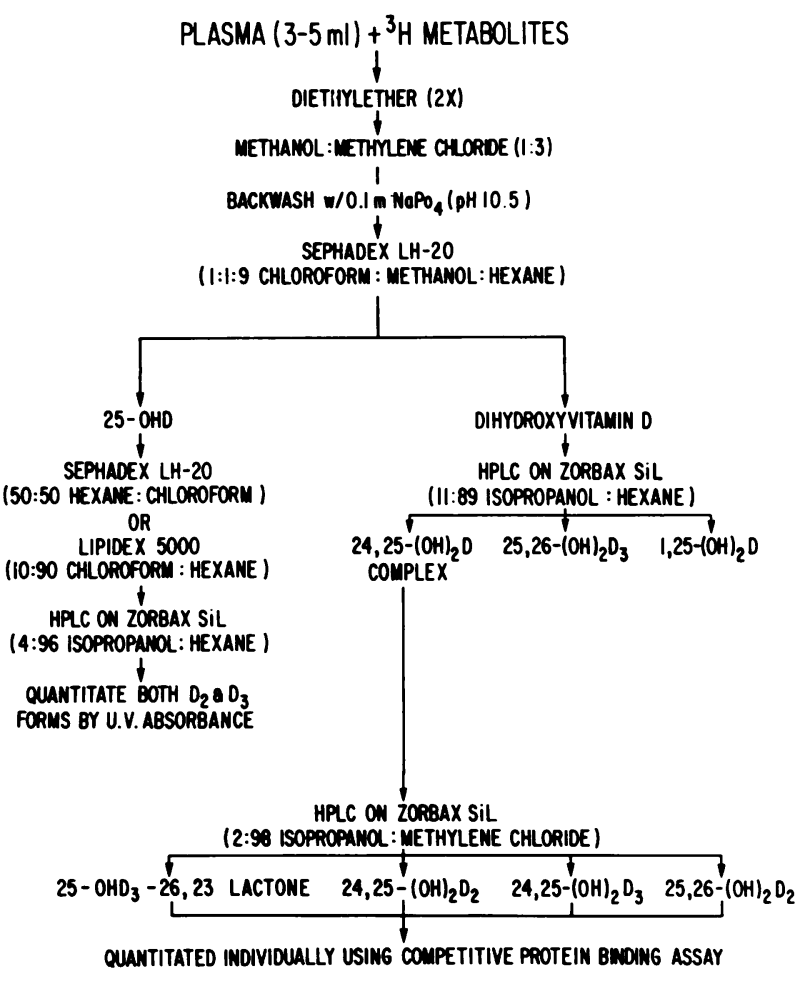

Figure 1 Procedure used for the isolation and measurment of $25-\mathrm{OHD}_{2}, 25-\mathrm{OHD}_{3}, 24,25-(\mathrm{OH})_{2} \mathrm{D}_{2}$, and $24,25-(\mathrm{OH})_{2} \mathrm{D}_{3}$.

higher in anephric plasma, and its presence was independent of vitamin $D(7)$. These substances were separated when the 24,25- $(\mathrm{OH})_{2} \mathrm{D}$ region from the first HPLC Zorbax Sil column was chromatographed on another HPLC Zorbax Sil column developed in 2:98 isopropanol:methylene chloride. The $24,25-(\mathrm{OH})_{2} \mathrm{D}_{2}$ and $24,25-(\mathrm{OH})_{2} \mathrm{D}_{3}$ regions (Fig. 3) were collected and measured by radioligand binding assays. The radioligand binding assays (8) were modified by adding $0.01 \%$ gelatin to the rat plasma, diluted $(1 / 5,000)$ in $0.05 \mathrm{M} \mathrm{NaPO}_{4}$ buffer ( $\mathrm{pH}$ 7.5). The addition of the gelatin resulted in higher specific binding than was obtained with diluted plasma alone and in little change in nonspecific binding (Fig. 4). No $\left[{ }^{3} \mathrm{H}\right] 24,25-(\mathrm{OH})_{2} \mathrm{D}_{2}$ was available for estimating the recovery of this metabolite, so we assumed a recovery similar to that of $24,25-(\mathrm{OH})_{2} \mathrm{D}_{3}$ because identical purification steps were used for the measurement of both $24,25-(\mathrm{OH})_{2} \mathrm{D}_{2}$ and $24,25-(\mathrm{OH})_{2} \mathrm{D}_{3}$. A typical standard curve for each metabolite is shown in Fig. 5.

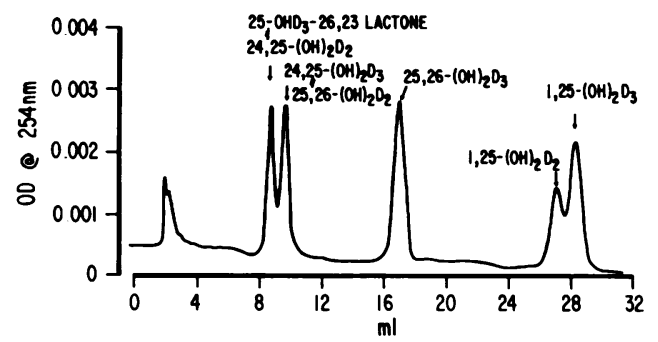

Figure 2 Elution of vitamin $\mathrm{D}_{2}$ and vitamin $\mathrm{D}_{3}$ metabolites from an HPLC Zorbax Sil column developed in 11:89 isopropranol:hexane with a flow rate of $2.0 \mathrm{ml} / \mathrm{min}$. 


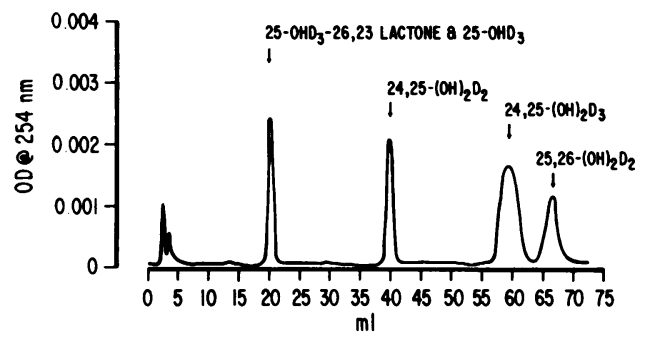

FIGURE 3 Elution of vitamin $\mathrm{D}_{2}$ and vitamin $\mathrm{D}_{3}$ metabolites from an HPLC Zorbax Sil column developed in 2:98 isopropanol:methylene chloride with a flow rate of $2.0 \mathrm{ml} / \mathrm{min}$.

Human blood samples. Blood samples were obtained from normal human volunteers and anephric patients who had been bilaterally nephrectomized at least 1 yr before our experiment. The samples for both groups were taken during August and September of 1979. In addition to their usual dietary sources, the anephric patients (with the exception of $A-8)$ received $1,000 \mathrm{IU} / \mathrm{d}$ of vitamin $\mathrm{D}_{2}$ orally.

Pig blood samples. Bilateral nephrectomy (anephrics) or sham-operation (controls) were performed on 5- to 6-wkold pigs ( 3 pigs/group) fed a diet containing normal concentrations $(2,200 \mathrm{IU} / \mathrm{kg}$ of diet $)$ of vitamin $\mathrm{D}_{3}$. On the day of surgery (day 0 ) and again on day 7 , the pigs were treated intramuscularly with $5 \times 10^{6}$ IU to vitamin $D_{3}$. All pigs, both anephrics and controls, were subjected to peritoneal dialysis twice daily for $45 \mathrm{~min}$ with $500 \mathrm{ml}$ of Ringer's solution that was modified to contain 5-10\% dextrose. The dialysis solution was introduced and removed through a chronically implanted catheter placed in the peritoneal cavity. Blood samples from these pigs were taken frequently (as shown in Fig. 6).

Identity of $24,25-(\mathrm{OH})_{2} \mathrm{D}_{3}$ generated in vivo in anephric pigs. At the end of the experiment the anephric pigs were bled. The plasma lipids were extracted as described (8). $24,25-(\mathrm{OH})_{2} \mathrm{D}_{3}$ was isolated and identified by mass spectroscopy; a Varian CH-7 mass spectrometer (Varian Associates, Palo Alto, Calif.) was used at $70 \mathrm{eV}$ with a direct probe inlet at $90^{\circ} \mathrm{C}$ above ambient temperature.

\section{RESULTS}

Vitamin D metabolites in human plasma. No 24, $25-(\mathrm{OH})_{2} \mathrm{D}_{3}$ was detected $(\leq 0.2 \mathrm{ng}-\mathrm{ml})$ in the plasma

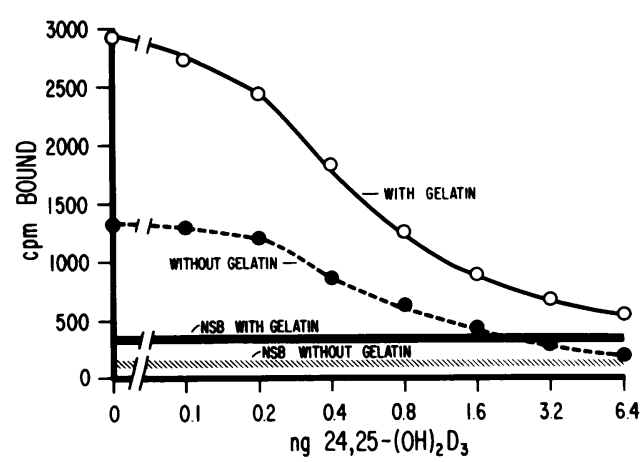

Figure 4 Influence of the addition of gelatin to the competitive protein binding assay for $24,25-(\mathrm{OH})_{2} \mathrm{D}_{3}$. The $y$ axis represents the counts per minute $\left[{ }^{3} \mathrm{H}\right] 25-\mathrm{OHD}_{3}$ bound. NSB, nonspecific binding.

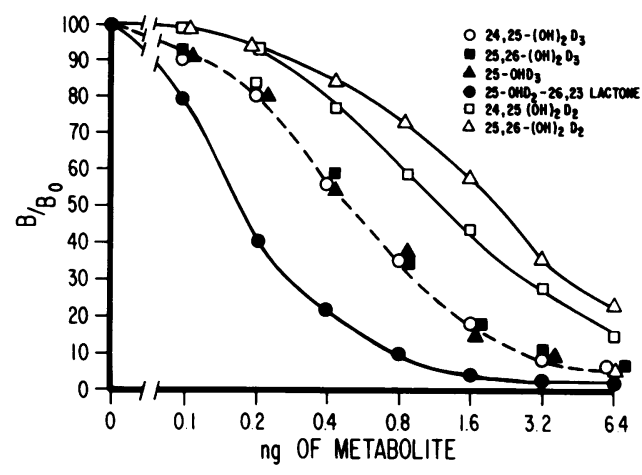

FIGURE 5 Relative binding of vitamin $D_{2}$ and vitamin $D_{3}$ metabolites in the competitive protein binding assay for $24,25-(\mathrm{OH})_{2} \mathrm{D}$.

of eight anephric humans (Table I). 24,25- $(\mathrm{OH})_{2} \mathrm{D}_{2}$ was detected in the plasma of two anephric patients, A-5 $(0.51 \mathrm{ng} / \mathrm{ml})$ and A-7 $(0.41 \mathrm{ng} / \mathrm{ml})$. Plasma 24,25$(\mathrm{OH})_{2} \mathrm{D}_{3}$, however, was detected (overall mean $\pm \mathrm{SE}$, $2.3 \pm 0.42)$ and was the major circulating form of 24,25 $(\mathrm{OH})_{2} \mathrm{D}$ in normal patients. Plasma $24,25-(\mathrm{OH})_{2} \mathrm{D}_{2}$ was not detected in three of the five normal humans and was very low in the other two normal humans (Table I).

Plasma 25-OHD concentrations were presented and summarized in Table I. 25-OHD concentrations were $31.7 \pm 3.6($ mean $\pm S E)$ in anephrics and 40.1 \pm 3.7 $($ mean $\pm \mathrm{SE})$ in normals. The contribution of 25hydroxyvitamin $\mathrm{D}_{2}\left(25-\mathrm{OHD}_{2}\right)$ to the total plasma 25-OHD pool ranged from $5.3-60 \%$ in anephrics and $3-5 \%$ in normals.

Vitamin $D_{3}$ metabolites in pig plasma. No vitamin $\mathrm{D}_{2}$ metabolites were detected in pig plasma; therefore, only the metabolites originating from vitamin $D_{3}$ will be reported.

The longitudinal changes in plasma $25-\mathrm{OHD}_{3}$, $24,25-(\mathrm{OH})_{2} \mathrm{D}_{3}$, and calcium are shown in Table II and

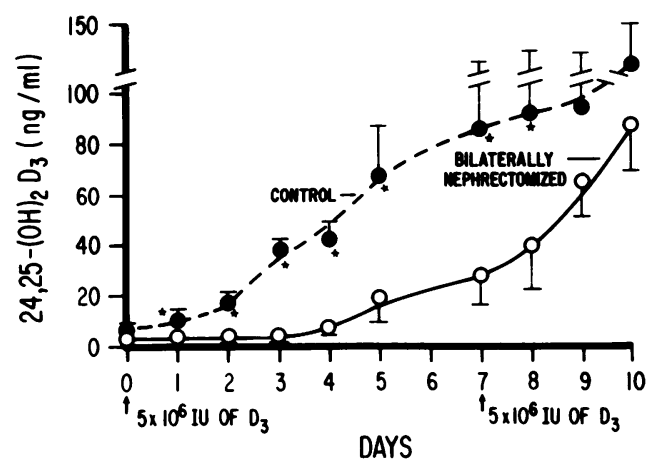

FIGURE 6 Changes in plasma $24,25-(\mathrm{OH})_{2} \mathrm{D}_{3}$ in anephric (bilaterally nephrectomized) and control pigs after intramuscular injections of vitamin $\mathrm{D}_{3}\left(5 \times 10^{6} \mathrm{IU}\right)$ on day $\mathrm{O}$ and again on day $7 .{ }^{*}, P<0.05$. 
TABLE I

25-OHD $2,25-\mathrm{OHD} D_{3}, 24,25-(\mathrm{OH})_{2} \mathrm{D}_{2}$, and $24,25-(\mathrm{OH})_{2} \mathrm{D}_{3}$ in Normal and Anephric Human

\begin{tabular}{|c|c|c|c|c|c|c|}
\hline \multirow[b]{2}{*}{ Group } & \multicolumn{6}{|c|}{ Metabolite } \\
\hline & $25-\mathrm{OHD}_{2}$ & $25-\mathrm{OHD}_{3}$ & Total 25-OHD & $24,25-(\mathrm{OH})_{2} \mathrm{D}_{2}^{*}$ & $24,25-(\mathrm{OH})_{2} \mathrm{D}_{3}{ }^{*}$ & Total $24,25-(\mathrm{OH})_{2} \mathrm{D}$ \\
\hline & & & & $n g / m l$ & & \\
\hline \multicolumn{7}{|l|}{ Anephric } \\
\hline A-1 & 25.6 & 16.2 & 41.8 & $<0.2$ & $<0.2$ & ND \\
\hline A-2 & 12.8 & 13.4 & 26.2 & $<0.2$ & $<0.2$ & ND \\
\hline A-3 & 15.3 & 32.1 & 47.4 & $<0.2$ & $<0.2$ & ND \\
\hline$A-4$ & 6.8 & 17.9 & 24.7 & $<0.2$ & $<0.2$ & ND \\
\hline A-5 & 10.7 & 10.0 & 20.7 & 0.51 & $<0.2$ & 0.51 \\
\hline A-6 & 10.8 & 25.6 & 36.4 & $<0.2$ & $<0.2$ & ND \\
\hline A-7 & 11.7 & 8.5 & 20.2 & 0.41 & $<0.2$ & 0.41 \\
\hline A-8 & 2.0 & 35.7 & 37.7 & $<0.2$ & $<0.2$ & ND \\
\hline Mean $\pm S E$ & $11.8 \pm 2.3$ & $19.9 \pm 3.6$ & $31.7 \pm 3.6$ & $0.26 \pm 0.12$ & $<0.2$ & $0.12 \pm 0.08$ \\
\hline \multicolumn{7}{|c|}{ Normal } \\
\hline $\mathrm{N}-1$ & 2.2 & 38.3 & 40.5 & 0.32 & 4.9 & 5.2 \\
\hline $\mathrm{N}-2$ & 2.4 & 31.4 & 33.8 & 0.36 & 1.5 & 1.9 \\
\hline $\mathrm{N}-3$ & 4.5 & 30.4 & 34.9 & $<0.2$ & 1.4 & 1.4 \\
\hline $\mathrm{N}-4$ & 1.7 & 35.8 & 37.5 & $<0.2$ & 2.2 & 2.2 \\
\hline N-5 & 3.7 & 50.2 & 53.9 & $<0.2$ & 3.2 & 3.2 \\
\hline Mean $\pm S E$ & $2.9 \pm 0.5$ & $37.2 \pm 3.6$ & $40.1 \pm 3.7$ & $0.26 \pm 0.07$ & $2.6 \pm 0.42$ & $2.8 \pm 0.70$ \\
\hline
\end{tabular}

* In samples with $<0.2 \mathrm{ng} / \mathrm{ml}$ of $24,25-(\mathrm{OH})_{2} \mathrm{D}$, a value of 0.2 was used in calculating the mean.

in Figs. 6 and 7. On day 0, just before surgery and the first vitamin $\mathrm{D}_{3}$ injection, the plasma $24,25-(\mathrm{OH})_{2} \mathrm{D}_{3}$ was $4.3 \pm 0.61 \mathrm{ng} / \mathrm{ml}$ in the control pigs and $3.6 \pm 0.6$ $\mathrm{ng} / \mathrm{ml}$ in the anephric pigs. In the anephric pigs, the plasma $24,25-(\mathrm{OH})_{2} \mathrm{D}_{3}$ declined slightly by day 2 to 3.2 $\mathrm{ng} / \mathrm{ml}$; however, on day 4 the plasma $24,25-(\mathrm{OH})_{2} \mathrm{D}_{3}$ began rising progressively to $87.0 \pm 18.4 \mathrm{ng} / \mathrm{ml}$ by day 10. In control pigs, the plasma $24,25-(\mathrm{OH})_{2} \mathrm{D}_{3}$ more than doubled from $4.3 \pm 0.6$ to $9.8 \pm 4.1 \mathrm{ng} / \mathrm{ml}$ by day 1 and progressively increased to $110.3 \pm 32.1 \mathrm{ng} / \mathrm{ml}$ by day 10 . Plasma 24,25- $(\mathrm{OH})_{2} \mathrm{D}_{3}$ concentrations in control pigs were higher than anephrics $(P<0.05)$ from day 1 to day 8. To positively identify the material measured as $24,25-(\mathrm{OH})_{2} \mathrm{D}_{3}$, we isolated $\sim 2 \mu \mathrm{g}$ of $24,25-(\mathrm{OH})_{2} \mathrm{D}_{3}$ from $50 \mathrm{ml}$ of pooled plasma from anephric pigs taken on day 10. The mass spectra (Fig. 8) confirmed the material as $24,25-(\mathrm{OH})_{2} \mathrm{D}_{3}$. The molecular ion at the ratio of mass to charge $(\mathrm{m} / \mathrm{e}) 416$ and the peaks at $(398$

TABLE II

Changes in 25-OHD $3,24,25-(\mathrm{OH})_{2} \mathrm{D}_{3}$, and Calcium (Ca) in Three Anephric and Three Control Pigs

\begin{tabular}{|c|c|c|c|c|c|c|}
\hline \multirow[b]{2}{*}{ Day } & \multicolumn{3}{|c|}{ Anephric } & \multicolumn{3}{|c|}{ Controls } \\
\hline & $25-\mathrm{OHD}_{3}$ & $24,25-(\mathrm{OH})_{2} \mathrm{D}_{3}$ & $\mathrm{Ca}$ & $25-\mathrm{OHD}_{3}$ & $24,25-(\mathrm{OH})_{2} \mathrm{D}_{3}$ & $\mathrm{Ca}$ \\
\hline & \multicolumn{2}{|c|}{$n g / m l$} & mg/dl & \multicolumn{2}{|c|}{$n g / m l$} & $m g / d l$ \\
\hline 0 & $12 \pm 4$ & $3.6 \pm 0.6$ & $8.4 \pm 0.1$ & $8 \pm 2$ & $4.3 \pm 0.6$ & $10.3 \pm 1.2$ \\
\hline 1 & $60 \pm 19$ & $2.8 \pm 0.7$ & $8.8 \pm 0.5$ & $64 \pm 11$ & $9.8 \pm 4.1$ & $10.1 \pm 0.3$ \\
\hline 2 & $267 \pm 94$ & $3.2 \pm 0.7$ & $13.7 \pm 0.7$ & $181 \pm 17$ & $17.8 \pm 2.7$ & $10.1 \pm 0.8$ \\
\hline 3 & $341 \pm 120$ & $4.6 \pm 0.9$ & $15.5 \pm 0.1$ & $212 \pm 14$ & $27.5 \pm 5.6$ & $10.9 \pm 0.9$ \\
\hline 4 & $422 \pm 126$ & $7.5 \pm 2.0$ & $16.2 \pm 0.2$ & $332 \pm 65$ & $41.5 \pm 8.6$ & $10.7 \pm 0.6$ \\
\hline 5 & - & - & - & - & - & - \\
\hline 6 & $433 \pm 86$ & $19.1 \pm 9.5$ & $13.3 \pm 0.5$ & $339 \pm 93$ & $66.7 \pm 21.8$ & $10.9 \pm 0.1$ \\
\hline 7 & $656 \pm 74$ & $26.7 \pm 11.7$ & $12.4 \pm 0.2$ & $438 \pm 42$ & $83.9 \pm 32.4$ & $10.8 \pm 0.7$ \\
\hline 8 & $576 \pm 96$ & $39.2 \pm 17.9$ & $12.7 \pm 0.4$ & $388 \pm 11$ & $89.8 \pm 31.4$ & $11.6 \pm 0.4$ \\
\hline 9 & $758 \pm 80$ & $65.4 \pm 14.3$ & $12.0 \pm 0.1$ & $367 \pm 24$ & $92.9 \pm 28.4$ & $10.7 \pm 1.1$ \\
\hline 10 & $705 \pm 62$ & $87.0 \pm 18.4$ & $11.7 \pm 0.2$ & $439 \pm 64$ & $110.3 \pm 32.1$ & - \\
\hline
\end{tabular}

After intramuscular injections of $5 \times 10^{6} \mathrm{IU}$ of vitamin $\mathrm{D}_{3}$ on day 0 and day 7. Data are given as the mean $\pm \mathrm{SE}$. 


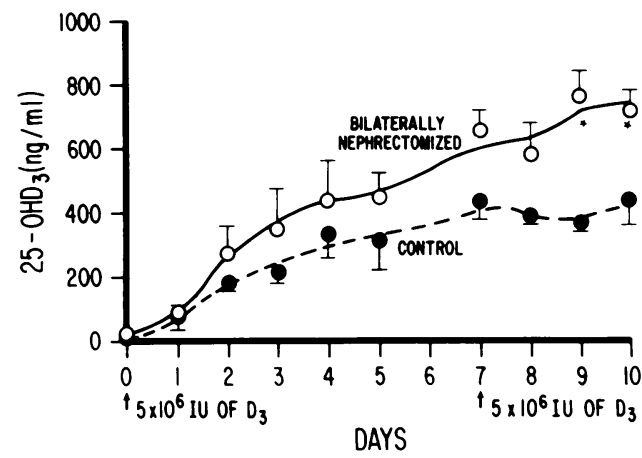

Figure 7 Changes in 25- $\mathrm{OHD}_{3}$ in anephric (bilaterally nephrectomized) and control pigs treated as described in Fig. 6. * $P<0.05$.

$\left.\mathbf{M}^{+}-\mathrm{H}_{2} \mathrm{O}\right), 383\left(\mathbf{M}^{+}-\mathrm{H}_{2} \mathrm{O}-\mathrm{CH}_{3}\right), 27 \mathbf{1}\left(\mathbf{M}^{+}\right.$-side chain), 253 $\left(271-\mathrm{H}_{2} \mathrm{O}\right.$ ), 136 (A ring plus carbons 6 and 7), and 118 $\left(136-\mathrm{H}_{2} \mathrm{O}\right)$ are consistent with the mass fragmentation of authentic $24,25-(\mathrm{OH})_{2} \mathrm{D}_{3}(12)$.

The plasma $25-\mathrm{OHD}_{3}$ concentrations in anephric and normal pigs are shown in Table II and Fig. 7. All the pigs had $25-\mathrm{OHD}_{3}$ concentrations ranging from 7 to $15 \mathrm{ng} / \mathrm{ml}$ on day 0 just before surgery. By day 1 , 25- $\mathrm{OHD}_{3}$ concentrations in both anephrics and controls had risen to $50-70 \mathrm{ng} / \mathrm{ml}$. By day 10 ( $3 \mathrm{~d}$ after the second vitamin $D_{3}$ injection), the anephric pigs had significantly higher $(P<0.05)$ concentrations $(705 \pm 62 \mathrm{ng} / \mathrm{ml})$ of $25-\mathrm{OHD}_{3}$ than control $(439 \pm 64$ $\mathrm{ng} / \mathrm{ml})$.

Plasma-Ca concentrations remained normal or slightly below $(8-10 \mathrm{mg} / \mathrm{dl})$ during days 0,1 , and 2 in both anephric and control pigs. Thereafter, a transient hypercalcemia was observed in the anephric pigs; Ca concentration $(16.2 \mathrm{mg} / \mathrm{dl})$ was highest on day 4 . Plasma Ca was slightly elevated in normals during days 8-10.

\section{DISCUSSION}

Our assay techniques, which involved an extension of purification procedures previously described (8), resulted in the demonstrations of very low to nondetectable levels of $24,25-(\mathrm{OH})_{2} \mathrm{D}$ in anephric human plasma. This result is in contrast to those in previous reports (7-9), in which detectable plasma 24,25$(\mathrm{OH})_{2} \mathrm{D}$ in anephric human plasma samples are described. Although none of the eight anephric patients in the present report had detectable plasma $24,25-(\mathrm{OH})_{2} \mathrm{D}_{3}$, two anephric patients (A-5 and A-7) had very low but detectable $24,25-(\mathrm{OH})_{2} \mathrm{D}_{2}$. Plasma $25-\mathrm{OHD}_{2}$ concentrations in these two patients $(10.7$ and $11.7 \mathrm{ng} / \mathrm{ml}$ ) were similar to those in most of the other anephric patients. The reason for the measurable $24,25-(\mathrm{OH})_{2} \mathrm{D}_{2}$ in these two patients is unknown.

Our results, therefore, confirm those of Taylor (10) who showed that extremely low or unmeasurable plasma $24,25-(\mathrm{OH})_{2} \mathrm{D}$ concentrations exist in anephric humans consuming normal dietary levels of vitamin D. This final resolution of whether $24,25-(\mathrm{OH})_{2} \mathrm{D}$ is produced in anephrics is very important because a great deal of experimental evidence suggests that 1,25-dihydroxyvitamin $\mathrm{D}\left[1,25-(\mathrm{OH})_{2} \mathrm{D}\right]$ is the only active hormonal form of vitamin $\mathrm{D}$ and is the only metabolite not produced in anephric humans (4). Although results in early studies suggest that 1,25$(\mathrm{OH})_{2} \mathrm{D}$ may be adequate for treating children with vitamin D deficiency (13), results in several other studies are in direct conflict with this concept $(11,14)$. In diseases in which plasma $24,25-(\mathrm{OH})_{2} \mathrm{D}$ and $1,25-$ $(\mathrm{OH})_{2} \mathrm{D}$ concentrations would be very low (vitamin $\mathrm{D}$ deficiency and renal osteodystrophy), treatment with $1,25-(\mathrm{OH})_{2} \mathrm{D}_{3}$ alone did not heal the osteomalacia associated with these diseases $(11,14)$. However,

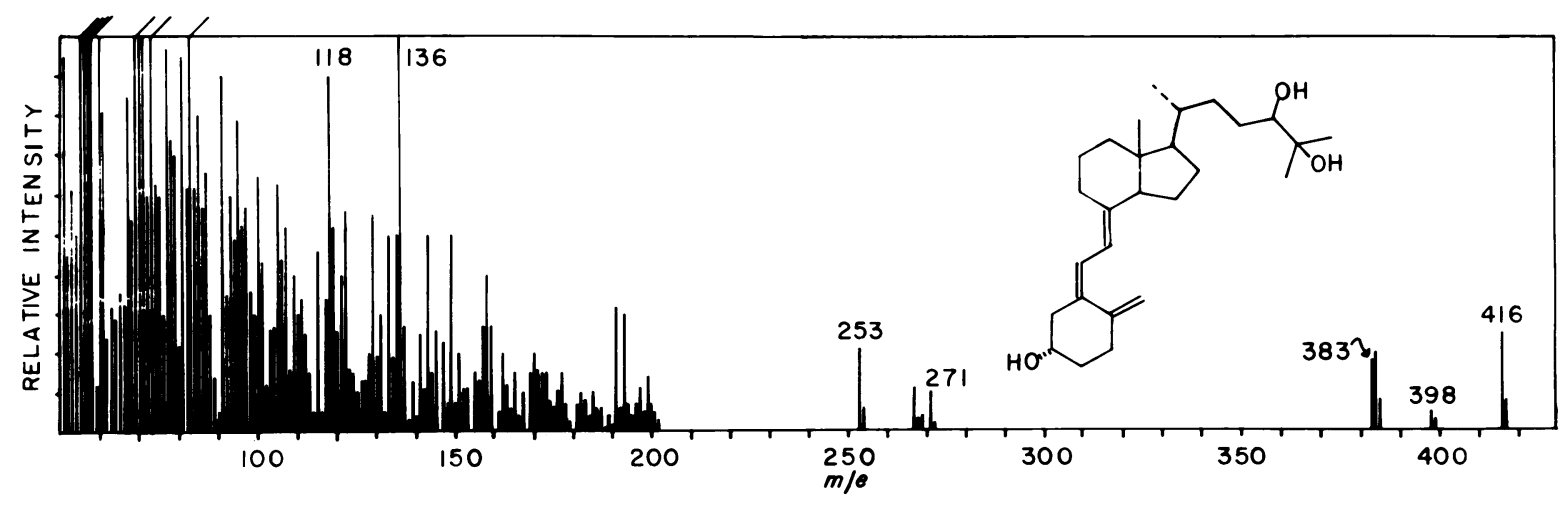

Figure 8 Mass spectrum of $24,25-(\mathrm{OH})_{2} \mathrm{D}_{3}$ isolated from anephric pigs. The $24,25-(\mathrm{OH})_{2} \mathrm{D}_{3}$ was isolated from plasma taken on day 10 of the experiment. The spectrum shows an average of two scans. The molecular ion at the ratio of mass to charge $(\mathrm{m} / \mathrm{e}) 416$ and the peaks at $\mathrm{m} / \mathrm{e} 398$ $\left(\mathrm{M}^{+}-\mathrm{H}_{2} \mathrm{O}\right), 383\left(\mathrm{M}^{+}-\mathrm{H}_{2} \mathrm{O}-\mathrm{CH}_{3}\right), 271\left(\mathrm{M}^{+}\right.$-side chain), $253\left(271-\mathrm{H}_{2} \mathrm{O}\right), 136$ (A ring plus carbons 6 and 7 ), and $118\left(136-\mathrm{H}_{2} \mathrm{O}\right)$ clearly shows that the compound is a dihydroxylated vitamin $\mathrm{D}_{3}$ derivative. The peaks at $\mathrm{m} / \mathrm{e} 271,253,136$, and 118 further show that the two additional hydroxyl groups are in the side chain. 
when $24,25-(\mathrm{OH})_{2} \mathrm{D}_{3}$ was given in addition to 1,25 $(\mathrm{OH})_{2} \mathrm{D}_{3}$, the resulting normal bone mineralization in patients with vitamin D-deficient osteomalacia $(11,14)$ suggested an active role for $24,25-(\mathrm{OH})_{2} \mathrm{D}_{3}$ in normal bone formation. Although untested, response to this dual treatment might be similar in patients with renal osteodystrophy.

Another important aspect of this study is whether anephrics of any species have the ability to produce $24,25-(\mathrm{OH})_{2} \mathrm{D}$ in extrarenal tissues such as the intestine (15) or bone (16). Taylor (10) has shown that $24,25-(\mathrm{OH})_{2} \mathrm{D}$ was not detectable in anephric humans with normal 25-OHD concentrations $(20-40 \mathrm{ng} / \mathrm{ml})$ or in anephric subjects with two- to threefold normal 25-OHD concentrations. Therefore, we used the anephric and control pigs injected with massive amounts of vitamin $D_{3}$ to assure the achievement of superphysiological plasma $25-\mathrm{OHD}_{3}$ concentrations. In these experiments, the control pigs had elevated plasma $24,25-(\mathrm{OH})_{2} \mathrm{D}_{3}$ concentration within $24 \mathrm{~h}$ after the initial massive injection of vitamin $\mathrm{D}_{3}$. In general, the plasma $24,25-(\mathrm{OH})_{2} \mathrm{D}_{3}$ concentrations in control pigs paralled the plasma $25-\mathrm{OHD}_{3}$ concentration so that by the end of the experiment the plasma $24,25-(\mathrm{OH})_{2} \mathrm{D}_{3}$ concentrations in control pigs had increased to 110 $\mathrm{ng} / \mathrm{ml}$. In contrast, the $24,25-(\mathrm{OH})_{2} \mathrm{D}_{3}$ concentrations in the anephrics had decreased slightly from presurgical concentrations of 3.6 to $2.8 \mathrm{ng} / \mathrm{ml}$ by day 1 and $3.2 \mathrm{ng} / \mathrm{ml}$ by day 2 (Fig. 6 and Table II). Plasma $24,25-(\mathrm{OH})_{2} \mathrm{D}_{3}$ in anephric pigs decreased during the same period in which plasma $25-\mathrm{OHD}_{3}$ concentrations were increasing. However, after day 4 , the $24,25-(\mathrm{OH})_{2} \mathrm{D}_{3}$ concentrations in the plasma of the anephric pigs progressively increased to $87.0 \pm 18.4 \mathrm{ng} / \mathrm{ml}$ by day 10 . Extrarenal 24-hydroxylation was first shown only when $25-\mathrm{OHD}_{3}$ concentrations had reached superphysiological concentrations of $>400 \mathrm{ng} / \mathrm{ml}$ (Figs. 6 and 7). The reason for the inability of anephric pigs to 24hydroxylate $25-\mathrm{OHD}_{3}$ when $25-\mathrm{OHD}_{3}$ is $<400 \mathrm{ng} / \mathrm{ml}$ is unknown. One explanation may be that the $K_{\mathrm{m}}$ for the $25-\mathrm{OHD}_{3}$ of the extrarenal 24-hydroxylase might be higher than the kidney 24-hydroxylase, and thus require more substrate for hydroxylation. Alternatively, the extrarenal enzyme may require several days for activation or stimulation. The first of these hypotheses seems more likely because all patients in our study had been nephrectomized for at least $1 \mathrm{yr}$. Presumably, this would be enough time for extrarenal 24-hydroxylase stimulation. Therefore, attempting to cause an elevation in plasma $24,25-(\mathrm{OH})_{2} \mathrm{D}$ in anephric patients by giving exogenous vitamin $D_{3}$ or $25-\mathrm{OHD}_{3}$ might lead to toxic side effects from the high plasma concentrations of $25-\mathrm{OHD}_{3}$ needed to satisfy the substrate concentration requirements of the extrarenal 24-hydroxylase enzyme. The hypercalcemic state of anephric pigs after vitamin $D_{3}$ injections in our experiment (Table II) supports this concept.

Conclusion. We have confirmed earlier findings (10) that $24,25-(\mathrm{OH})_{2} \mathrm{D}$ is very low to nondetectable in anephric humans consuming normal dietary levels of vitamin $D$. This result conflicts with results in previous work (7-9). From our results, it is apparent that the other purification methods (7-9) for $24,25-(\mathrm{OH})_{2} \mathrm{D}$ determination do not adequately resolve material that will compete in the competitive protein-binding assay. We did not detect any $25,26-(\mathrm{OH})_{2} \mathrm{D}_{2}$ or 25 $\mathrm{OHD}_{3}-26,23$ lactone in normal or anephric human plasma. Apparently, therefore, other compounds (possibly peak I in Horst et al. [8]) not related to vitamin D were measured as $24,25-(\mathrm{OH})_{2} \mathrm{D}$; previous results, therefore, are erroneous. Although our system for 24 , $25-(\mathrm{OH})_{2} \mathrm{D}$ measurement is more laborious than that of Taylor (10), it has the advantage of being able to isolate and measure other metabolites of vitamin $D_{2}$ and vitamin $\mathrm{D}_{3}$.

Finally, we have shown that anephric pigs produce $24,25-(\mathrm{OH})_{2} \mathrm{D}_{3}$ when given pharmacological doses of vitamin $D_{3}$ to cause superphysiological plasma 25 $\mathrm{OHD}_{3}$ concentrations of $>400 \mathrm{ng} / \mathrm{ml}$.

\section{ACKNOWLEDGMENTS}

We wish to thank Mrs. C. A. Hauber, Mrs. R. L. Lyon, Mr. R. D. Evans, and Mr. P. A. Herrig for their expert technical assistance.

This work was supported in part by National Institutes of Health grant A.I 26535 and Robert A. Welch Foundation grant I-797 and by National Institutes of Health grants A.M 22014 and RR 00058.

Disclaimer statement. Mention of a trade name, proprietary product, or vendor does not constitute a guarantee or warranty by the U.S. Department of Agriculture and does not imply its approval to the exclusion of other products or vendors that may be suitable.

\section{REFERENCES}

1. Fraser, D. R., and E. Kodichet. 1970. Unique biosynthesis by kidney of a biologically active vitamin $D$ metabolite. Nature (Lond.). 228: 764-766.

2. Knutson, J. C., and H. F. DeLuca. 1974. 25-Hydroxyvitamin $\mathrm{D}_{3}$-24-hydroxylase. Subcellular location and properties. Biochemistry. 13: 1543-1548.

3. Tanaka, Y., R. A. Shepard, H. F. DeLuca, and H. K. Schnoes. 1978. The 26-hydroxylation of 25-hydroxyvitamin $\mathrm{D}_{3}$ in vitro by chick renal homogenates. Biochem. Biophys. Res. Commun. 83: 7-13.

4. DeLuca, H. F. 1979. The vitamin D system in the regulation of calcium and phosphorus metabolism. Nutr. Rev. 37: 161-193.

5. Horst, R. L., and E. T. Littledike. 1980. 25-OHD $-26,23$ lactone: demonstration of kidney-dependent synthesis in the pig and rat. Biochem. Biophys. Res. Commun. 93: $149-154$.

6. Garabedian, M., H. Pavlovitch, C. Fellot, and S. Balsan. 1974. Metabolism of 25-hydroxyvitamin $D_{3}$ in anephric rats: a new active metabolite. Proc. Natl. Acad. Sci. U. S. A. 71: 554-557. 
7. Haddad, J. G., Jr., C. Min, M. Mendelsohn, E. Slatopolsky, and T. J. Hahn. 1977. Competitive proteinbinding radioassay of 24,25-dihydroxyvitamin $D$ in sera from normal and anephric subjects. Arch. Biochem. Biophys. 182: 390-395.

8. Horst, R. L., R. M. Shepard, N. A. Jorgensen, and H. F. DeLuca. 1979. The determination of 24,25-dihydroxyvitamin $\mathrm{D}$ and 25,26-dihydroxyvitamin $\mathrm{D}$ in plasma from normal and nephrectomized man. J. Lab. Clin. Med. 93: 277-285.

9. Shepard, R. M., R. L. Horst, A. J. Hamstra, and H. F. DeLuca. 1979. Determination of vitamin $D$ and its metabolites in plasma from normal and anephric man. Biochem. J. 182: 55-69.

10. Taylor, C. M. 1977. The measurement of 24,25-dihydrocholecalciferol in human serum. In Vitamin D: Biochemical, Chemical and Clinical Aspects Related to Calcium Metabolism. A. W. Norman, K. Schaefer, D. V. Herrath, H.-G. Grigoleit, J. W. Coburn, H. F. DeLuca, E. B. Mawer, T. Suda, editors. Walter De Gruyter, Berlin. 541-545.

11. Bordier, D., H. Rasmussen, P. Marie, L. Miravet, J. Gueris, and A. Ryckwaert. 1978. Vitamin D metabolites and bone mineralization in man. J. Clin. Endocrinol. Metab. 46: 284-294.

12. Holick, M. F., H. K. Schnoes, H. F. DeLuca, R. W. Gray, I. T. Boyle, and T. Suda. 1972. Isolation and identification of 24,25-dihydroxycholecalciferol, a metabolite of vitamin $\mathrm{D}_{3}$ made in the kidney. Biochemistry. 11: 4251-4255.

13. Balsan, S., M. Garabedian, R. Sorgniard, M. F. Holick, and H. F. DeLuca. 1975. 1,25-Dihydroxyvitamin $D_{3}$ and $1 \alpha$-hydroxyvitamin $\mathrm{D}_{3}$ in children: biological and therapeutic effects in nutritional rickets and different types of vitamin D resistance. Pediatr. Res. 9: 586-597.

14. Bordier, P., J. Zingraff, J. Gueris, P. Jungers, P. Marie, M. Pechet, and H. Rasmussen. 1978. The effect of $1 \alpha-$ $\mathrm{OHD}_{3}$ and $1 \alpha, 25-(\mathrm{OH})_{2} \mathrm{D}_{3}$ on the bone in patients with renal osteodystrophy. Am. J. Med. 64: 101-107.

15. Kumar, R., H. K. Schnoes, and H. F. DeLuca. 1978. Rat intestinal 25-hydroxyvitamin $\mathrm{D}_{3}$ and $1 \alpha$,25-dihydroxyvitamin $\mathrm{D}_{3}$-24-hydroxylase.J. Biol. Chem. 253: 3804-3809.

16. Garabedian, M., M. B. DeBois, M. T. Corval, E. Pezant, and S. Balsan. 1978. Vitamin D and cartilage. I. In vitro metabolism of 25-hydroxycholecalciferol by cartilage. Endocrinology. 102: 1262-1268. 